\title{
Reflexões teóricas sobre o texto aplicadas à tradução
}

\author{
Marcelo Raupp ${ }^{1}$
}

O problema da tradução é um problema de
linguística do texto. Ao traduzir, devemos indagar
o que e como diríamos nessa mesma situação, na
outra comunidade linguística, caracterizada,
entre outras coisas, por tradições culturais
diferentes das nossas.

Eugênio Coseriu

Abstract: This article intends to present a brief discussion about the text, applied to the translation activity, in order to emphasize the idea that translators deal in their day by day with a social phenomenon that reflects the particularities of the environment where it was produced and that the construction of the meaning is conditioned to the contextualization of such phenomenon in its original socialcultural environment.

Keywords: text; context; translation studies.

Resumo: 0 presente artigo objetiva apresentar uma rápida discussão sobre texto, aplicada à atividade tradutória, com vistas a reforçar a ideia de que os tradutores lidam no seu dia a dia com um fenômeno social que reflete as especificidades do ambiente em que foi produzido e que a construção do significado está condicionada à contextualização desse fenômeno no seu ambiente sociocultural de origem.

Palavras-chave: texto; contexto; estudos da tradução.

\footnotetext{
${ }^{1}$ Doutorando em Estudos da Tradução pela Universidade Federal de Santa Catarina. Mestre em Estudos da Tradução e Bacharel em Letras Português e Inglês - Secretariado Executivo Bilíngue, ambos pela mesma universidade. Email: mrraupp@yahoo.com.br.
} 


\section{Introdução}

Este artigo traz questões teóricas relativas ao texto, discutindo, de forma breve, os fatores que estão por detrás dessa entidade que, quando escrita em língua estrangeira, é a matéria-prima daqueles que se dedicam à atividade tradutória. 0 assunto é apresentado em duas grandes seções: a primeira aborda o impacto da correlação entre língua, cultura e sociedade na escrita de um texto; e a segunda traz algumas considerações teóricas sobre 0 texto propriamente dito, correlacionando-as com a tradução.

\section{Considerações sobre o impacto da}

\section{correlação entre língua, cultura e sociedade na escrita de um texto}

COSTA (1992: 133-134) afirma que o trabalho do tradutor é baseado em uma mensagem que já existe na forma de um texto escrito em outra língua. Podemos perceber que Costa cita o texto como a entidade em que é materializada e exposta a mensagem que 0 tradutor deve transpor na língua para a qual traduz. Sobre a escrita de um texto, é necessário ter em mente que ela está condicionada à correlação que existe entre língua e o meio em que ambas se manifestam: o contexto cultural e o contexto situacional. Sendo assim, antes de discutirmos brevemente o conceito de texto, vejamos a correlação que há entre língua e cultura, que, juntamente com o contexto situacional, condiciona a escrita de um texto.

Em que consiste a cultura? O filósofo alemão HERDER (apud LYONS 1987: 273) pondera que nada é mais indeterminado do que esse termo. Apesar disso, propostas de definições não faltam. HUDSON (apud LyONS 1987: 274), por exemplo, observa que a cultura é uma espécie de conhecimento adquirido 
socialmente, ou seja, é o conhecimento que alguém possui em virtude de ser membro de uma determinada sociedade. Já Faraco (apud FerRARO 2008: 154) propõe que cultura é o conjunto constituído pelos valores socioculturais articulados às formas da língua, valores esses que são comuns a determinados grupos sociais, mas não o são em outros, e que funcionam como um elemento de identificação de cada grupo. A proposta de definição apresentada pelo Dicionário Houaiss da Língua Portuguesa agrega elementos do pensamento de Hudson e Faraco, pois registra que cultura é o conjunto dos padrões de comportamento, crenças, conhecimentos, costumes e outros valores morais e materiais, que caracterizam um grupo social e o distingue de outro.

Podemos depreender, então, que o relacionamento interpessoal em sociedade parece ser a peça-chave na formação de uma cultura. No entanto, é necessário ter em mente que há um encadeamento recíproco e intrínseco entre uma cultura e a língua através da qual ela é manifesta. É o que nos diz LOTMAN (apud MILTON 1998: 35), quando observa que uma cultura não pode existir se não tiver no seu centro a estrutura de uma língua natural, da mesma forma que uma língua não pode existir se não estiver inserida no contexto de uma cultura. Conforme Bloomfield (apud BenVENISTE 1976: 13), é essa reciprocidade intrínseca entre linguagem e cultura que torna a língua uma das nossas principais fontes de conhecimento da cultura (ou do mundo da significação) de um povo. Além disso, Lyons (1987: 279) observa que muitos dos conceitos com que lidamos são vinculados à cultura, no sentido de que dependem, para a sua compreensão, do conhecimento transmitido socialmente, tanto conhecimento prático quanto propositivo, que variam consideravelmente de cultura para cultura.

Levando em conta essas considerações sobre cultura, é possível perceber que há um ponto em comum entre elas. E parece que este ponto em comum nada mais é do que a realidade social de cada cultura, que é construída em parceria com a língua, por meio da qual se tem acesso aos valores socioculturais de um povo. Sendo assim, o conjunto formado por língua e cultura, conforme sustenta SAPIR (apud MILTON 1998: 36), é o meio de 
expressão de uma sociedade, um guia para a realidade social, que varia de uma cultura para outra, pois nenhum par de línguas é suficientemente idêntico, a tal ponto de representar a mesma realidade social. Segundo SAPIR (apud MILTON 1998: 36), os mundos em que vivem diferentes sociedades são distintos, não o mesmo com rótulos diferentes.

\section{O texto e a tradução}

COSERIU (1980: 98) declarou que o problema da tradução é um problema de linguística do texto, e que, ao traduzir, devemos indagar o que e como diríamos nessa mesma situação, na outra comunidade linguística, caracterizada, entre outras coisas, por tradições culturais diferentes das nossas. Mas, em que consiste o texto? Em que consiste essa entidade que, quando escrita em língua estrangeira, é a matéria-prima daqueles que se dedicam à atividade tradutória? De acordo com HalLIDAY (apud VASCONCELLOS, Pagano 2005: 183), o texto não é um receptáculo de conteúdo estável e imutável, mas um fenômeno social, cuja construção do significado depende, essencialmente, de dois fenômenos relativos à sociedade: o contexto situacional, que é o ambiente imediato em que o texto se realiza, e 0 contexto cultural, que abarca, além do ambiente imediato, os aspectos culturais envolvidos no ato comunicativo. Esses dois contextos são imprescindíveis para que um texto seja compreendido.

Também de acordo com Halliday (apud Vasconcellos, Pagano 2005: 184), os textos são reflexos das línguas, que, por sua vez, são sistemas que os seres humanos utilizam, em contextos sociais, para modelar a realidade, a qual será mapeada textualmente de acordo com a maneira com que cada língua enxerga o mundo. A propósito, com relação à linguagem como sistema modelador, LotMAn (apud MILTON 1998: 35) postula que a língua é o sistema modelador primário de uma sociedade, enquanto que a literatura e a arte em geral são sistemas modeladores secundários, pois são derivados da própria 
RAUP, M. Reflexões teóricas sobre o texto aplicadas à tradução

língua. É digno de nota que essa imanente relação que há entre língua e sociedade parece já ter sido considerada por SAUSSURE (1989: 33), o qual afirmou o seguinte no seu famoso Curso de Linguística Geral: "o objeto concreto de nosso estudo é, pois, o produto social depositado no cérebro de cada um, isto é, a língua".

Além disso, conforme Costa (1992: 133-134) e Vasconcellos e Pagano (2005: 176), tudo parece indicar que os textos são entidades provisórias, pois a formulação linguística que os falantes utilizam para representar, por intermédio do texto, determinada realidade é apenas uma dentre as várias alternativas disponibilizadas pelo contexto sociocultural. Sob esse prisma, toda tradução também pode ser considerada uma entidade provisória na língua de chegada, já que é uma dentre as várias possibilidades de manifestar o conteúdo originalmente expresso na língua de partida, o que, segundo COSTA (1992: 133-134), torna o texto traduzido uma entidade independente, mas que, ao mesmo tempo, está intimamente ligada com a sua fonte. É o que parece também nos dizer PAZ (2006: 11), de outra maneira:

Cada texto é único e, simultaneamente, é a tradução de outro texto. Nenhum texto é inteiramente original, porque a própria linguagem em sua essência já é uma tradução: primeiro, do mundo não verbal e, depois, porque cada signo e cada frase é a tradução de outro signo e de outra frase. Mas esse raciocínio pode se inverter sem perder sua validade: todos os textos são originais porque cada tradução é distinta. Cada tradução é, até certo ponto, uma invenção e assim constitui um texto único.

Convém acrescentarmos que, segundo HAwKES (apud MiLTon 1998: 35), embora o cerne de toda tradução seja uma atividade linguística, o processo tradutório também envolve uma série de fatores extralinguísticos. Por esse motivo, HAwKES (apud MILTON 1998: 35) defende que a passagem de um texto de uma língua para outra é uma operação que pertence mais à Semiótica, ou seja, à ciência que estuda os sistemas, as estruturas, os processos e as funções desempenhadas pelos símbolos (e aqui não devemos esquecer que a língua é um sistema de símbolos). Conforme observa COSTA (1992: 133-134), os 
RAUP, M. Reflexões teóricas sobre o texto aplicadas à tradução

fatores extralinguísticos envolvidos no processo tradutório impõem muitas restrições (culturais e ideológicas, por exemplo) ao trabalho do tradutor, o que, de certa forma, acaba tirando a liberdade desse profissional de manipular o texto-fonte, a fim de torná-lo compreensível na cultura de chegada. Nesse mesmo viés, MATTHIESSEN (apud ZUNIGA 2006: 31) destaca que traduzir é um processo semiótico que abrange os sistemas que estão por trás do par linguístico e cultural envolvido no ato tradutório, sistema esse que parece reger todas as línguas e cujo conhecimento pleno, ao que tudo parece indicar, só pode ser atingido mediante a aprendizagem de, pelo menos, uma língua estrangeira, visto que é comparando as línguas que se terá noção de como a linguagem funciona, independente do idioma que se considera.

KLEIN (apud EMMEL 1998: 113) também faz algumas considerações pertinentes sobre texto, aplicadas à atividade tradutória. Para esse estudioso, traduzir é uma aplicação especial da competência linguística humana. E ele explica: alguém que escreve um texto pode refletir livremente sobre como revestirá de palavras e sentenças as ideias que deseja expressar. Isso já não ocorre com quem traduz um texto, visto que as ideias que compõem a mensagem a ser expressa já estão pré-determinadas e revestidas de palavras e sentenças, que refletem as especificidades socioculturais da língua em que o texto foi originalmente escrito. Sendo assim, conforme KLeIN (apud EMMEL 1998: 113), os processos de compreensão e de produção textual, os quais ocorrem separados um do outro, estão interligados na atividade tradutória e ainda envolvendo sistemas socioculturais e linguísticos distintos, o que faz 0 tradutor assumir tanto o papel de receptor do texto de partida como de emissor do texto de chegada. Essa mesma questão também é discutida por PAZ (2006: 12). Ele observa, por exemplo, que:

O ponto de partida do tradutor não é a linguagem em movimento, [...] mas a linguagem fixa [...]. Sua operação é inversa à do [autor]: não se trata de construir com signos móveis um texto móvel, mas de desmontar os elementos deste texto, pôr de novo em circulação os signos e devolvê-los à linguagem. A atividade do tradutor é paralela à do [autor], com esta diferença marcante: ao escrever, [o autor] não sabe como será seu [texto]; ao traduzir, [o tradutor] sabe que seu 
[texto] deverá reproduzir o [texto] que tem diante dos olhos. O [texto] traduzido deverá reproduzir o [...] original, que [...] não é sua cópia e sim sua transmutação. 0 ideal da tradução [...] consiste em produzir, por meios diferentes, efeitos análogos.

Deste modo, sob a ótica do funcionalismo, na passagem de um texto de uma língua para outra, o tradutor é o responsável por extrair a substância das palavras e sentenças do texto em língua estrangeira e expressá-la na língua para a qual traduz, fazendo as adaptações necessárias, de modo que o texto elaborado sob o outro pano de fundo sociocultural torne-se compreensível na cultura de chegada.

\section{Considerações finais}

Diante da breve discussão aqui apresentada, vimos que os textos são fenômenos sociais, cuja escrita está condicionada pela forte correlação que há entre língua, cultura e sociedade. Vimos também que a língua é o meio para acessar a cultura de uma sociedade. Vimos que os textos refletem as visões de mundo e as especificidades socioculturais do ambiente em que se originaram. Vimos que a construção do significado de um texto requer que este esteja inserido na cultura e no ambiente imediato de origem. Vimos ainda que traduzir não é apenas uma operação entre línguas, mas também entre contextos culturais e situacionais.

Tudo isso que vimos parece confirmar que o papel primordial do tradutor é intermediar contextos, o que o torna uma espécie de ponte entre ambientes socioculturais distintos. E parece que uma intermediação dessa natureza requer um exame minucioso das especificidades e das visões de mundo do par linguístico envolvido no ato tradutório, de modo que o tradutor busque, na língua de chegada, formulações linguísticas que produzam um efeito semelhante ao produzido pelas formulações linguísticas da língua de partida. 


\section{Referências bibliográficas}

BenVenISTe, É. Problemas de linguística geral. São Paulo: Ed. da USP, 1976, p. 13.

COSERIU, E. Lições de linguística geral. Rio de J aneiro: Ao Livro Técnico, 1980, p. 98.

COSTA, W. The translated text as re-textualisation. In: Ilha do Desterro. Studies in translation. Florianópolis, n. 28, 1992, p. 133, 134.

FerRaro, M. L. et al. Experiência e prática de redação. Florianópolis: Ed. da UFSC, 2008, p. 154.

KLEIN, W. O que a Tradutologia pode esperar da Linguística? Tradução: Ina Emmel. In: O "fazer" terminológico X o "fazer" tradutório. Uma aplicação prática na área de especialidade: tradutologia. Dissertação (Mestrado em Linguística) - Programa de Pós-graduação em Linguística, Universidade Federal de Santa Catarina, Florianópolis, 1998, p. 113.

LYoNs, J . Linguagem e linguística: uma introdução. Rio de J aneiro: LTC, 1987, p. $273,274,279$.

MILToN, J. Tradução: teoria e prática. São Paulo: Martins Fontes, 1998, p. 3536.

PAZ, O. Tradução: Literatura e Literariedade. Tradução: Doralice Alves de Queiroz. Belo Horizonte: UFMG, 2006, p. 5-6, 11-12. Disponível em: বttp:// www. letras. ufmg. br/ site/ publicacoes/ download/ traducaolite ratura-site.pdf $>$. (23/04/2009).

Saussure, F. Curso de linguística geral. 15. ed. São Paulo: Cultrix, 1989, p. 33.

VASCONCELlos, M. L.; PAgano, A. Explorando interfaces: Estudos da Tradução, Linguística Sistêmico-Funcional e Linguística de Corpus. In: Competência em Tradução: Cognição e Discurso. Belo Horizonte: UFMG, 2005, p. 176, 179, 183, 184, 190.

ZUNIGA, G. R. F. Construing the translator: a meta-reflection grounded in corpus-based translation studies and systemic functional linguistics. Dissertação (Mestrado em Letras/ Inglês e Literatura Correspondente) Programa de Pós-graduação em Letras/Inglês e Literatura Correspondente, Universidade Federal de Santa Catarina, Florianópolis, 2006, p. 31. 